\title{
Review
}

\section{Politicising digital space: Theory, the internet and renewing democracy}

\author{
Trevor Garrison Smith \\ University of Westminster Press, London, 2017, 143pp., \\ ISBN 978-1-911534-40-2
}

Contemporary Political Theory (2020) 19, S59-S62. https://doi.org/10.1057/s41296018-0273-9; published online 28 October 2018

According to Trevor Garrison Smith, political theorists have yet to make the leap into the digital age. We are wedded to models of democratic deliberation and participation where bodily presence is regarded as a prerequisite for an authentic politics. Many of us still think that the gold standard for democracy as something akin to the Athenian polis, where presence ensures the full and active engagement of all participants in a process of communal decision-making. It's a model that still haunts our thinking about how a truly democratic politics works, whether it be via studiously confected deliberative forums or assemblies enacting a 'prefigurative', directly democratic politics. It's only in a sense by being physically somewhere that we can be regarded as full-fledged political actors in our own right. By contrast, the view that we can be just as effective operating in cyberspace is one that is often dismissed as 'clicktivism' or 'slacktivism', terms that drip with barely disguised contempt for the view that we can be political participants using online platforms.

The aim of this lively and engaging book is to demonstrate how both positions are misguided and how, therefore, a move to the online can augment and enhance democracy in important ways. Smith does so by offering a compelling critique of democratic theory mobilising in particular the work of Hannah Arendt and Jacques Rancière in defence of an activist reading of democracy that insists on the centrality of citizens as participants in their own right. With Arendt, he finds that representative democracy enshrines a separation of those who act, the politicians and representatives, from those who are passive in relation to the political process itself, the rest of us. With Rancière, he finds that democratic theory all too easily gives up on the idea that 'anyone and everyone' can take part in the process of decision-making, lapsing into variants of Platonic elitism. The image he builds is similar to the one we find in, for example, Bernard Manin's critique of representative democracy, where - for the most part - citizens are reduced to an 'audience' for political actors literally and metaphorically removed from the daily lives of those they represent. Smith's aim is to demonstrate how, by embracing the

(C) 2018 Springer Nature Limited. 1470-8914 Contemporary Political Theory Vol. 19, S1, S59-S62 
idea of online engagement, we can reboot democracy in the direction of a kind of virtual polis, a political sphere in which every citizen can act in authentic and telling ways to the benefit of the community.

This is bold theorising of a welcome kind, given what is at stake: no less than the renewal and indeed reinvention of democracy in a digital age. It proceeds by laying bare the inadequacies of current thinking about what is implied in online engagement, offering case studies and examples of where the use of online tools has facilitated political mobilisation and the creation of democratic experiments. Frequent reference is made to Anonymous, the hacktivist collective that has mobilised on a number of occasions to prevent governments from closing down cyberspace. He also discusses events such as the Arab Spring and Occupy, both of which demonstrate - the author thinks - the power of online tools to create a sense of community amongst those with shared concerns. This allows him to tackle the slacktivist critique, i.e. the view that a focus on the online necessarily induces a kind of passivity, as opposed to fostering real, i.e. bodily, engagement with the political.

On the other hand, these cases don't help the central argument, which is that we ought to shift more decision-making into the online sphere in order to facilitate greater citizen involvement. It's a pity therefore that some of the more important developments in this area weren't considered. These include the process of the refoundation of the Icelandic constitution through a process of online deliberation. They also include experiments in participatory governance in major cities, such as Barcelona and Madrid, using online tools to encourage citizens to prioritise aims and objectives for municipal governance. If Smith had looked into these processes, one wonders how they might have affected the tone of the argument.

One of the features of the shift to online governance in cities (and I write as someone who has studied these processes at close hand in Spain) is that citizens seem reluctant to engage in it. Participation rates remain doggedly low. This might of course be due to a lack of time, particularly amongst more disadvantaged parts of the population who are often forced to hold down several jobs, as well as undertake carer duties. It may be a lack of confidence in terms of engaging in online argumentation, which - after all - requires a certain level of literacy, never mind fluency, in order to permit full engagement. Major cities are also home to large numbers of recent immigrants whose command and grasp of the local language, particularly in its written form, might prove an obstacle to providing confident responses. We can note as well that, just because anyone and everyone can enter an online discussion, it doesn't mean that asymmetries of information that often distort debates in non-online environments somehow disappear.

It's also somewhat surprising that Smith makes only scant reference to the potential for disruption posed by those beyond the relevant political community itself. It's one thing to manage the views and opinions of those inside the community, such as trolls whose main aim is often to provoke, but it's quite 
another to deal with the challenges posed by those driven by more malign purposes. As 'advanced' democracies are finding, trying to maintain coherent and effective online operations against cyber attacks - whether by rival states, by corporations, or by motivated groups of individuals like, well, Anonymous - is proving to be more than just a temporary headache: it's one of the most serious threats contemporary policing has to manage. If more policy formation and decision-making are shifted online, we can expect these threats will become more serious as the stakes get higher.

Does all this constitute enough of a concern to undermine the central thesis being developed here, which is that moving more decision-making online will promote greater engagement by citizens, enhanced democracy, and thereby overcome that sense of almost existential crisis experienced representative democracy?

The lack of empirical examples in the book inevitably means that we are short of the kind of confirming evidence we need in order to let go of the representative paradigm, which is so deeply implanted in our thinking about how democracy functions. One of the reasons why we have representative institutions is, to quote J.S. Mill 'to prevent us from being misgoverned' (1972, p. 202) - code for preventing the majority from getting its hands on the levers of power. Elites don't like direct democracy, and its easy to see why: they lose the power to shape matters to their own benefit.

What is harder to weigh is whether, given the opportunity, citizens would be keen to step up from occasional participants to shapers of the policy process. It's not as if the business of self-governance is a straightforward one. Under contemporary conditions, it is anything but. The policy process doesn't get any easier because of the much larger number of participants involved in it. Budgetary decisions don't become less divisive the more citizens are involved. The time taken to resolve complex matters as regard transportation, schooling, housing won't decrease because more citizens get involved. In short, direct democracy does not provide a shortcut past complexity. If anything, it is likely to add to it.

Arendt and Rancière are to Smith too ready to give up on the ideal of the Athenian polis in favour of, respectively, an aristocratic model of political action and an activist model of society as a counterweight to the state. Yet, his model begs more questions than theirs, both in terms of operationalization and desirability. It's not as if, after all, internet-based direct democracy doesn't have its own advocates. It does. In Europe, we find various actors not least the Pirate Party, the Liquid Democracy Initiative and various internet parties advocating for this kind of democratic participation. For the large part, citizens seem curiously unmoved by the prospect of being co-participants in democratic decision-making. Clearly, internet-based democracy is an idea whose time has not quite come. Whether it ever will, is a matter about which one can only conjecture. None of which of course is to diminish Smith's initiative to push these ideas forward within democratic

(C) 2018 Springer Nature Limited. 1470-8914 Contemporary Political Theory $\quad$ Vol. 19, S1, S59-S62 S61 
theory. This is a book, finely written, which prompts important questions and deserves wide readership.

\section{Reference}

Mill, J.S. (1972). Three Essays. Oxford: Oxford University Press.

Simon Tormey

University of Sydney, Sydney, NSW 2006, Australia simon.tormey@sydney.edu.au 